\title{
Model Pembelajaran Cooperative Integrated Reading and Composition based on Flipped Classroom Learning (CIRC-b-FCL)
}

\author{
Jufrizal ${ }^{1}$, Eka Sustri Harida ${ }^{* 2}$,Hermawati Syarif ${ }^{3}$, Ratmanida ${ }^{4}$, dan \\ Rayendriani Fahmei Lubis ${ }^{5}$ \\ Institut Agama Islam Negeri Padangsidimpuan ${ }^{2,5}$ \\ Universitas Negeri Padang $1,3,4$ \\ Corresponding Email: ${ }^{1}$ ekasustri@iain-padangsidimpuan.ac.id
}

\begin{abstract}
This study aims to determine the students' attitude in learning reading comprehension at English Program IAIN Padangsidimpuan by using CIRC-bFCL model. The research was done by using quantitative study by using questionnaires as the instrument. The data were analysed statistically. The students' attitude was seen from the students' cognitive, affective, and psychomotoric result (Ahmadi, 2007). By the result, it was seen that the students' attitude is better by using this model, it was seen by the result of cognitive (81.83) and psychomotor (82) are very good, and the effective attitude (77.08) was good. So, it can be concluded that the CIRC-b-FCL can be used for the students' attitude in learning reading comprehension.
\end{abstract}

Keywords: reading comprehension, students' attitude, and CIRC-b-FCL Model.

\begin{abstract}
Abstrak
Penelitian ini bertujuan untuk mengetahui sikap mahasiswa dalam pembelajaran reading comprehension pada Program Studi Tadris Bahasa Inggris IAIN Padangsidimpuan dengan menggunakan model pembelajaran CIRC-bFCL. Penelitian ini dilakukan secara kuantitatif dengan menggunakan angket sebagai instrument pengumpulan data, dan data dianalisis secara kuantitatif. Sikap mahasiswa ditinjau dari kognitif, afektif, dan psikomotorik (Ahmadi, 2007). Hasil penelitian menunjukkan bahwa sikap kognitif dan psikomotorik sangat baik, dan sikap afektif dalam kategori baik. Oleh karena itu dapat disimpulkan bahwa model pembelajaran CIRC-b-FCL dapat digunakan untuk memperbaiki sikap mahasiswa dalam pembelajaran reading comprehension.

Kata kunci: membaca pemahaman, sikap mahasiswa, dan CIRC-b-FCL Model.
\end{abstract}

\section{PENDAHULUAN}

Pembelajaran di Indonesia mengalami berbagai masalah dikarenakan pandemic Covid-19 yang belum usai. Permasalahan bisa muncul dari aspek guru, siswa, sarana, dan lain sebagainya (Aji, 2020; Mastura \& Santaria, 2020). Proses pembelajaran berubah dari sistem luring (luar jaringan) atau offline menjadi dalam jaringan (daring) atau online. Ketidaksiapan menghadapi penggunaan teknologi dalam pembelajaran yang terlalu mendadak, dan ketidaklengkapan fasilitas pembelajaran menggunakan IT (Information and 
Technology) menjadi alasan utama permasalahan pembelajaran tersebut muncul. Permasalahan yang muncul hendaknya menjadi perhatian banyak pihak, bukan saja oleh guru, tetapi juga siswa, pemerhati Pendidikan, bahkan pemerintah.

Proses pembelajaran yang tiba-tiba dilaksanakan secara daring ini mengakibatkan kekagetan akademis bukan saja bagi mahasiswa namun juga bagi para dosen, dan tenaga kependidikan. Bukan hanya proses perkuliahan yang dilaksanakan secara online, tetapi juga pelayanan akademis harus dilakukan secara online. Ketidaksiapan fasilitas dan sumber daya yang tepat guna dalam memanfaatkan teknologi menjadi hambatan bagi pelaksanaan proses kegiatan akademik. Walaupun tidak dipungkiri bahwa dampak positif dari pelaksanaan pembelajaran pada masa Covid-19 ini juga baik adanya, salah satunya menjadikan mahasiswa, dosen, dan tenaga kependidikan memiliki literasi digital (Firman, 2020), hal ini terbukti dengan peningkatan penggunaan teknologi dalam pembelajaran.

Kemampuan membaca masyarakat Indonesia untuk membaca teks akademis yang berbahasa Inggris masih sangat lemah (Wijayanti, 2020). Hal ini juga ditambah lagi dengan keberadaan Covid-19 ini, dimana pembelajaran reading di perguruan tinggi juga berdampak negatif pada mahasiswa (Harida, 2020). Sehingga permasalahan pembelajaran semakin kompleks, sehingga kemampuan mahasiswa juga tidak bisa dimaksimalkan. Sebagaimana diketahui bahwa kemampuan membaca teks Bahasa Inggris mahasiswa masih belum memuaskan. Hal ini terlihat dari data dibawah ini:

Tabel 1 Data Statistik Kemampuan Awal Membaca Mahasiswa Statistics

NilaiReading
\begin{tabular}{|l|r|}
\hline N $\quad$ Valid & 30 \\
Missing & 0 \\
Mean & 54.87 \\
Median & 56.00 \\
Mode & 56 \\
Std. Deviation & 12.042 \\
Sum & 1646 \\
\hline
\end{tabular}

Sumber: Pengolahan Data Eka Sustri Harida (2021)

Nilai tersebut apabila diinterpretasikan kepada nilai rata-rata yang disarankan oleh Riduwan (2009) hanya berada pada kategori cukup. Apabila 
langsung dilihat salah satu indikator untuk mengetahui kemampuan mahasiswa dalam memahami paragraf adalah kemampuan mencari ide utama. Dari data ditemukan bahwa kurang dari 50\% (sekitar 47\%) mahasiswa yang mampu menemukan ide utama di dalam paragraf.

Tabel 2 Data Kemampuan Mahasiswa dalam Menemukan Main Idea

\begin{tabular}{rrrr}
\hline Nomor & $\begin{array}{c}\text { Nomor soal tentang } \\
\text { Main Idea }\end{array}$ & $\begin{array}{c}\text { Jumlah Mahasiswa yang } \\
\text { benar }\end{array}$ & Persentase \\
\hline \hline 1 & 3 & 19 & 63,33 \\
\hline 2 & 5 & 19 & 63,33 \\
\hline 3 & 17 & 26 & 86,67 \\
\hline 4 & 20 & 9 & 30,00 \\
\hline 5 & 31 & 7 & 23,33 \\
\hline 6 & 45 & 16 & 53,33 \\
\hline 7 & 49 & 2 & 6,67 \\
\hline \hline Jumlah & & & 326,67 \\
\hline Persentase & & & $47 \%$ \\
\hline \hline
\end{tabular}

Sumber: Pengolahan Data Eka Sustri Harida (2021)

Sehubungan dengan hal tersebut, maka perlu kiranya ditemukan solusi untuk membantu memecahkan masalah tersebut. Hal ini dilakukan dalam rangka membantu meningkatkan kemampuan membaca pemahaman mahasiswa, khususnya untuk memahami informasi yang ada dalam paragraf dapat diperoleh dengan maksimal.

Lemahnya kemampuan membaca mahasiswa disebabkan oleh beberapa faktor, salah satunya adalah penggunaan model pembelajaran tradisional yang seharusnya sudah ditinggalkan, karena sudah tidak cocok lagi dengan kondisi dan perkembangan zaman (Tularam \& Machiesella, 2018). Penyebab lainnya adalah kurang tepatnya metode pembelajaran yang digunakan, begitupun dengan proses pembelajaran yang berlangsung. Proses pembelajaran akan sangat berpengaruh pada hasil belajar mahasiswa (Saputra, 2015). Apabila proses pembelajaran tidak berlangsung dengan baik dan maksimal akan mengakibatkan tidak maksimalnya penguasaan mahasiswa terhadap materi pembelajaran yang diberikan. Proses pembelajaran dapat diperbaiki dengan menggunakan model pembelajaran yang cocok bagi pembelajaran tertentu. Ketidaksesuaian model pembelajaran yang digunakan saat ini menjadi salah satu alasan dikembangkannya model pembelajaran melalui penelitian pengembangan yang dilakukan ini. 
Penyediaan model pembelajaran berbasis internet serta terintegrasi antara satu keterampilan dengan keterampilan lainnya dapat menjadi solusi bagi permasalahan tersebut. Oleh karena itu, melalui penelitian Research and Development telah dimunculkan sebuah model pembelajaran untuk memberikan solusi bagi permasalahan tersebut (Harida, 2021c, 2021a). Model tersebut adalah Cooperative Integrated Reading and Composition based on Flipped Classroom Learning (CIRC-b-FCL), dan model ini dianggap valid dan layak digunakan untuk pembelajaran reading di perguruan tinggi.

Model pembelajaran CIRC-b-FCL ini adalah sebuah model pembelajaran kooperatif dengan menggunakan teknologi sederhana. Kolaborasi antara pembelajaran kooperatif dengan flipped classroom learning (FCL) menjadi karakteristik dari model ini. CIRC-b-FCL didefinisikan sebagai model pembelajaran integrasi antara CIRC dan FCL untuk pembelajaran understanding paragraph yang dikembangkan untuk mencapai tujuan pembelajaran di IAIN Padangsidimpuan (Harida, 2021b). Penggabungan model pembelajaran kooperatif CIRC dan model kelas terbalik FCL menjadikan kekuatan untuk menutupi kelemahan masing-masing model. Model CIRC tidak cocok untuk mahasiswa yang memiliki lemah dalam menangkap pembelajaran, namun dengan FCL maka mahasiswa disiapkan untuk belajar secara mandiri, secara otonomi dalam rangka pemerolehan informasi yang diinginkan. Selanjutnya proses penyampaian informasi yang diperoleh melalui pembelajaran terbalik yang dilaksanakan di luar kelas, agar hasilnya maksimal dikuatkan dengan proses pembelajaran kooperatif CIRC di dalam kelas. Kekuatan, kelemahan, dan keampuhan dalam meningkatkan kemampuan belajar para pelajar telah dibuktikan oleh beberapa penelitian (Bataineh \& Al-Sakal, 2021; Fitriani \& Nurjamaludin, 2020; Halili \& Zainuddin, 2015; Harida, 2021a; Slavin, Madden, Farnish, \& Stevens, 1995; Sofiana, 2018).

Melalui model CIRC-b-FCL yang telah diakui kevalidan dan kepraktisan penggunaannya, maka diyakini bahwa model ini juga dapat bermanfaat bagi perbaikan sikap mahasiswa dalam belajar. Oleh karena itu, dalam artikel ini akan dideskripiskan tentang efektifitas model pembelajaran tersebut terhadap sikap mahasiswa dalam pembelajaran reading. 


\section{METODE PENELITIAN}

Penelitian ini dilakukan secara kuantitatif dengan menggunakan angket dan pedoman observasi sebagai instrumen penelitian. Angket dikembangkan berdasarkan pendapat dari Ahmadi (2007), bahwa dosen dapat menilai sikap mahasiswa melalui 3 (tiga) aspek, yakni aspek kognitif (10 butir soal), afektif (8 butir soal), dan psikomotorik (7 butir soal). Angket disusun kedalam 25 item pertanyaan dalam bentuk skala Likert dengan pilihan Sangat Setuju, Setuju, Tidak Setuju, dan Sangat Tidak Setuju. Observasi dilakukan pada pelaksanaan proses pembelajaran dengan melihat semangat belajar, motivasi, minat, antusiasme, aktif, dan kedisiplinan. Sebanyak 17 (tujuh belas) orang mahasiswa dipilih secara acak untuk menjawab pertanyaan yang diberikan. Data yang diperoleh dianalisis secara statistic dengan mencari nilai rata-rata dan persentase dari masing-masing sikap mahasiswa terhadap pembelajaran.

\section{HASIL DAN PEMBAHASAN}

Sikap mahasiswa terhadap model pembelajaran CIRC-b-FCL yang telah digunakan kepada mahasiswa dilihat dari aspek kognitif, afektif, dan psikomotorik. Namun sebelum masuk pada sikap mahasiswa yang tergambar melalui 3 (tiga) aspek tersebut, perlu digambarkan sikap mahasiswa secara umum yang diperoleh dari hasil observasi yang dilakukan oleh rekan sejawat penulis. Dalam proses pembelajaran sikap mahasiswa dapat dilihat dari 6 (enam) aspek, yakni semangat belajar, motivasi, minat, antusiasme, aktif, dan kedisiplinan. Sikap tersebut tergambar dalam tabel di bawah:

Tabel 3 Penilaian Sikap Mahasiswa dari Observasi

\begin{tabular}{rlrr}
\hline No. & $\begin{array}{c}\text { Aspek Sikap yang } \\
\text { dinilai }\end{array}$ & $\begin{array}{c}\text { Pertemuan } \\
\text { Pertama }\end{array}$ & $\begin{array}{c}\text { Pertemuan } \\
\text { Kedua }\end{array}$ \\
\hline \hline 1 & Semangat & 2 & 2 \\
\hline 2 & Motivasi & 2 & 2 \\
\hline 3 & Minat & 2 & 2 \\
\hline 4 & Antusias & 2 & 2 \\
\hline 5 & Aktif & 2 & 2 \\
\hline 6 & Disiplin & 1 & 2 \\
\hline & Jumlah & 11 & 12 \\
\hline & Persentase & $92 \%$ & $100 \%$ \\
\hline
\end{tabular}


Dari tabel di atas terlihat bahwa pada pertemuan pertama mahasiswa memiliki sikap yang sangat baik dalam menghadapi pembelajaran dengan model CIRC-b-FCL yakni 92\% (kriteria sangat baik). Selanjutnya untuk pertemuan kedua, aspek sikap yang dinilai dapat terpenuhi oleh mahasiswa seluruhnya, artinya $100 \%$ mahasiswa memiliki sikap yang sangat baik secara keseluruhan terhadap model pembelajaran, baik dari segi semangat belajar, motivasi, minat, antusiasme, aktif, dan kedisiplinan.

Selanjutnya sikap mahasiswa pada model pembelajaran CIRC-b-FCL yang diperoleh melalui angket didesripsikan dalam tabel di bawah:

Tabel 4. Kalkulasi Penilaian Sikap Mahasiswa dari Kuisioner

\begin{tabular}{rlrr}
\hline \hline No & Aspek Sikap & Rata-rata & Persentase \\
\hline 1 & Kognitif & 81,83 & $82 \%$ \\
\hline 2 & Afektif & 77,08 & $77 \%$ \\
\hline 3 & Tingkah Laku & 82,38 & $82 \%$ \\
\hline \hline \multicolumn{2}{c}{ Sumber: Pengolahan Data Eka Sustri Harida $(2021)$}
\end{tabular}

Dari aspek kognitif, kalkulasi sikap mahasiswa ada pada nilai rata-rata 81,83 dengan persentase $82 \%$, artinya sejumlah $82 \%$ mahasiswa memiliki sikap yang baik terhadap peningkatan aspek kognitif. Selanjutnya untuk sikap afektif, seperti minat belajar, motivasi, dan keaktifan belajar dengan jumlah rata-rata 77.08 atau $77 \%$ mahasiswa memiliki sikap yang baik dalam peningkatan aspek afektif mereka. Terakhir dari aspek psikomotorik atau tingkah laku, sejumlah 82\% mahasiswa memiliki aspek perubahan pada tingkah laku mereka. Dengan demikian dapat dikatakan bahwa model pembelajaran ini membawa dampak yang cukup baik bagi perkembangan sikap mahasiswa.

Dari data ini diperoleh diketahui bahwa secara keseluruhan, sikap mahasiswa terhadap model ini cukup baik terhadap pembelajaran yang mereka lalui. Nilai persentase kalkulasi nilai dari kuisioner yang diperoleh ada pada level $80 \%$, artinya mahasiswa menilai "sangat baik" pada model yang digunakan ini. Sehingga dapat disimpulkan bahwa model ini cukup membawa pengaruh yang baik untuk sikap mahasiswa, karena interpretasi nilai sikap mahasiswa ada pada level sangat baik.

Berikut gambaran hasil kuisioner penilaian terhadap sikap mahasiswa. 


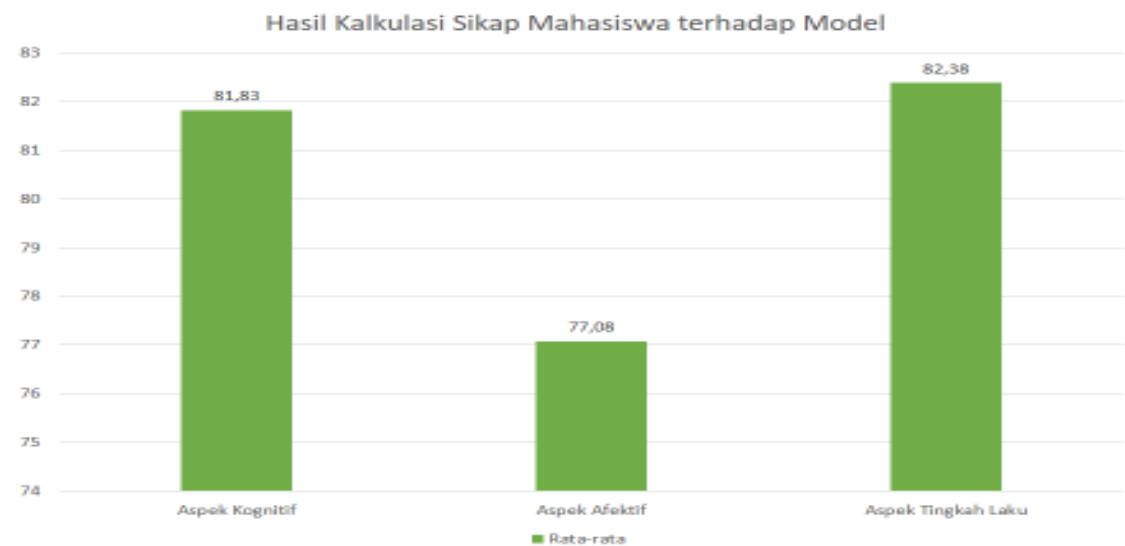

Grafik 1. Hasil Kalkulasi Nilai Sikap Mahasiswa terhadap Model

Dari gambaran di atas terlihat bahwa Model Pembelajaran CIRC-b-FCL memberikan dampak yang cukup baik bagi sikap kognitif dan tingkah laku mahasiswa, yakni sejumlah lebih dari $80 \%$ mahasiswa. Perubahan sikap afektif tidak begitu terlihat dari penggunaan model ini, hanya $77 \%$ mahasiswa yang merasakan dampak positif dari penggunaan model ini.

Nilai perolehan tersebut bila diinterpretasikan kepada rentang nilai yang berlaku di IAIN Padangsidimpuan termasuk dalam kategori sangat baik, yakni A (Siregar, dkk., 2019). Nilai A diperoleh dengan rentang 80 - 90 dalam Buku Panduan Akademik yang berlaku, oleh karena itu dapat dinyatakan bahwa model ini membawa hasil yang baik bagi peningkatan sikap mahasiswa dalam pengetahuan, yakni membaiknya kognitif mahasiswa tentang pemahaman paragraf.

Berkaitan dengan sikap afektif, dari hasil angket yang disebarkan kepada mahasiswa, maka diperoleh data bahwa untuk perubahan sikap secara afektif maka hanya berada pada level baik, hal ini dikarenakan nilai rata-rata perolehan dari angket hanya pada 77,08. Namun dalam hal sikap berkaitan dengan aspek tingkah laku, penilaian berada pada level 82,38 atau $82 \%$ persen mahasiswa mengalami peningkatan dalam hal tingkah laku.

Dengan perolehan hasil tersebut maka dapat dikatakan bahwa model yang diimplementasikan kepada mahasiswa dalam pembelajara reading di perguruan tinggi dapat dikatakan efektif dalam memperbaiki sikap mahasiswa. Sehingga dapat disimpulkan bahwa Model Pembelajaran CIRC-b-FCL ini dinyatakan efektif untuk digunakan dalam pembelajaran reading di perguruan 
tinggi khususnya pada mahasiswa Tadris Bahasa Inggris Fakultas Tarbiyah dan Ilmu Keguruan IAIN Padangsidimpuan.

Model pembelajaran Flipped Classroom ini telah banyak membuktikan keberhasilan dalam meningkatkan hasil belajar Bahasa Inggris. Sebagai contoh penelitian yang dilakukan dengan melihat kemanfaatan flipped terhadap listening comprehension (Astri, Syarif, \& Ningsih, 2019). Penelitian ini menghasilkan bahwa kemampuan mendengarkan siswa lebih baik melalui model flipped ini. Selanjutnya, dilihat dari pemanfaatan pembelajaran flipped untuk pembelajaran writing (Elvi, Syarif, \& Refnaldi, 2020). Siswa diketahui memerlukan pembelajaran flipped ini untuk meningkatkan kemampuan menulis Bahasa Inggris mereka. Selanjutnya flipped ini juga cocok digunakan untuk pembelajaran speaking (Sudarmaji, Anwar, \& Mulyana, 2021), model ini mampu meningkatkan kemampuan berbiacara Bahasa Inggris siswa. Begitupula dengan reading, banyak penelitian telah membuktikan bahwa pembelajaran kelas terbalik ini sesuai untuk pembelajaran reading (Bataineh \& Al-Sakal, 2021; Fahmi, Friatin, \& Irianti, 2020; Hassan Mahmoud, 2020). Kemampuan membaca menjadi meningkat dengan menggunakan model pembelajaran flipped, sehingga banyak digunakan oleh para guru atua dosen dan para pelaku Pendidikan untuk membantu pelaksanaan proses pembelajaran, utamanya dalam proses pembelajaran yang menggunakan blended system. Berdasarkan hasil ini, penulis mempertimbangkan penggunaan model CIRC-b-FCL untuk pembelajaran reading di perguruan tinggi.

Model pembelajaran CIRC-b-FCL ini dikembangkan juga dengan memperhatikan hasil penelitian yang mengangkat tentang CIRC terhadap reading. Beberapa hasil penelitian membuktikan bahwa model ini cukup efektif dalam meningkatkan kemampuan membaca para pelajar (Asrifan, Octaberlina, \& Ali, 2021) dan (Erlidawati \& Syarfuni, 2018). Dari hasil penelitian mereka terbukti bahwa model CIRC dapat membantu para pelajar dalam memahami teks berbahasa Inggris dengan baik. Dengan demikian dapat dikatakan bahwa model CIRC akan bermanfaat untuk pembelajaran reading, walaupun sebenarnya model ini lebih khusus dikembangkan untuk pembelajaran di sekolah menengah, bukan pada perguruan tinggi (Slavin, dkk., 1995). Namun tidak ada salahnya melakukan penelitian dengan menggunakan model ini bagi mahasiswa, disinilah letak novelty penelitian ini, bahwa ternyata model CIRC ini ternyata bermanfaat untuk pembelajaran reading di perguruan tinggi. 
Sebagaimana diketahui bahwa model pembelajaran yang integratif dapat sangat membantu para pelajar dalam memahami pembelajaran yang mereka lalui. Hal ini terbukti dari kolaborasi antara pembelajaran kooperatif dengan model pembelajaran lainnya. Penelitian Ristanto dan kawan-kawan (2021) dan Sofiana (2018) terbukti bahwa perpaduan model CIRC dengan model pembelajaran lainnya menghasilkan kemampuan membaca mahasiswa menjadi lebih baik. Kolaborasi antara CIRC dan Scientific Approach dan Role-Playing dapat mengaktifkan para pelajar dalam mengikuti pembelajaran, dan meningkatkan kemampuan membaca pada teks yang diberikan. Hal ini tentu mendukung teori yang disampaikan oleh John Dewey (2001) yang menyatakan bahwa pemecahan masalah melalui demokrasi di dalam kelompok akan membawa hasil yang lebih baik. Manusia merupakan makhluk sosial yang kodratnya adalah saling bekerjasama, dengan bekerjasama dalam kelompok, pemecahan masalah akan lebih cepat diperoleh. Olehkarena itu difahami bahwa perpaduan antara CIRC selaku pembelajaran dengan model kelompok berkolaborasi dengan model lainnya dapat membawa faedah yang lebih baik bagi hasil dan proses pembelajaran.

Selanjutnya, kolaborasi model pembelajaran juga dibuktikan dengan berhasilnya FCL bersama model lainnya dalam meningkatkan kemampuan membaca. Hal ini dibuktikan dengan hasil penelitian Tse, dkk., (2019) yang telah berhasil meningkatkan motivasi membaca siswa dengan melakukan pembelajaran menggunakan video melalui model flipped ini. Hasil kolaborasi flipped learning dengan model lainnya ditunjukkan oleh Fong dan Hong (2020) yang menyatakan bahwa penggabungan antara flipped learning dengan SQ3R strategi dapat meningkatkan kemampuan membaca peserta didik, sehingga disarankan untuk digunakan sebagai salah satu model pembelajaran reading.

Dengan beragam hasil tersebut, maka model pembelajaran CIRC-b-FCL ini juga dapat disarankan sebagai sebuah model pembelajaran yang inovatif dalam meningkatkan proses pembelajaran untuk memperbaiki hasil pemahaman mahasiswa terhadap bacaan yang dibacanya. Berangkat dari teori konstruktivisme, kognitivisme, dan behaviorisme, model ini memadukan keahlian mahasiswa dalam belajar membentuk makna, belajar sesuai dengan kapabilitas masing-masing sehingga dapat berubah menjadi lebih baik. Dengan demikian diyakini bahwa model pembelajaran CIRC-b-FCL ini dapat bermanfaat juga untuk meningkatkan pemahaman mahasiswa terhadap teks Bahasa Inggris 
yang dibacanya. Model ini juga diharapkan dapat menjadi solusi tidak hanya bagi pembelajaran reading di IAIN padangsidimpuan, sehingga kelemahan mahasiswa dalam membaca dapat diatasi (Harida, 2014, 2017), namun juga di berbagai lokasi. Sayangnya dalam tulisan ini, penulis baru dapat mengeksplorasi model ini terhadap sikap mahasiswa secara umum, belum mengkaji secara mendalam efektifitas model ini pada sikap-sikap akademis lainnya, seperti minat membaca secara lebih spesifik. Kemungkinan untuk penggunaan model ini bagi pembelajaran lain, juga penulis sarankan, karena dalam penelitian yang dilihat hanya pada pembelajaran reading, lebih spesifik pada materi pemahaman paragraf.

\section{KESIMPULAN}

Penggunaan model pembelajaran CIRC-b-FCL terhadap pembelajaran redaing di perguruan tinggi telah terbukti dapat memperbaiki sikap mahasiswa menjadi lebih baik. Peningkatan dalam aspek kognitif dan psikomotorik yang berada pada kriteria sangat baik, merupakan nilai positif dari model pembelajaran ini. Walaupun dalam hal peningkatan sikap mahasiswa dalam aspek psikomotorik model ini kurang berhasil secara maksimal, karena hanya berhasil membawa mahasiswa kepada kepuasan psikomotorik pada level baik, dengan persentase $77 \%$, namun model ini dapat dinyatakan sebagai model yang berhasil dalam memperbaiki sikap mahasiswa terhadap pembelajaran. Olehkarena itu dapat disimpulkan bahwa model CIRC-b-FCL ini dapat memperbaiki sikap mahasiswa menjadi lebih baik.

Dengan demikian dapat disarankan bahwa model CIRC-b-FCL ini juga bisa dikembangkan atau digunakan untuk melihat aspek sikap lainnya yang lebih spesifik. Selain itu juga model ini disarankan dapat digunakan diberbagai level pendidikan, bukan saja di perguruan tinggi tetapi juga di level sekolah menengah yang mempelajari Bahasa Inggris, bukan hanya untuk keterampilan reading, tetapi juga untuk keterampilan lainnya, seperti speaking, listening, dan writing. 


\section{DAFTAR PUSTAKA}

Ahmadi, A. (2007). Psikologi sosial. Jakarta: Rineka Cipta.

Aji, R. H. S. (2020). Dampak Covid-19 pada Pendidikan di Indonesia: Sekolah, Keterampilan, dan Proses Pembelajaran. SALAM: Jurnal Sosial \& Budaya Syar-I, 7(5), 395-402. https://doi.org/10.15408/sjsbs.v7i5.15314

Asrifan, A., Octaberlina, L. R., \& Ali, A. (2021). The Cooperative Integrated Reading and Composition (CIRC) Strategy in teaching reading comprehension. ScienceOpen Preprints. https://doi.org/10.14293/S21991006.1.SOR-.PPMY3FC.V1

Astri, U. S., Syarif, H., \& Ningsih, K. (2019). The Effect of Flipped Classroom Strategy on Listening Comprehension of Undergraduate Students at English Department in IAIN Batusangkar. The 1st International Conference on Education Social Sciences and Humanities (ICESSHum 2019), 316-321. Batusangkar: Atlantis Press. https://doi.org/10.2991/ICESSHUM-19.2019.51

Bataineh, R., \& Al-Sakal, R. (2021). To flip or not to flip: Potential effects on EFL reading comprehension. International Journal of Curriculum and Instruction, 13(2). Retrieved from http://ijci.wcciinternational.org/index.php/IJCI/article/view/548

Dewey, J. (2001). Democracy and Education. Pennsylvania: The Pennsyilvania State University. Retrieved from https://id1lib.org/ireader/783873

Elvi, Syarif, H., \& Refnaldi. (2020). Students' voices on their needs of models of teaching for writing skills. The 7th International Conference on English Language and Teaching (ICOELT 2019), 51-57. Atlantis Press. https://doi.org/10.2991/assehr.k.200306.010

Erlidawati, \& Syarfuni. (2018). The effect of Cooperative Integrated Reading and Composition on reading comprehension of IAIN Lhokseumawe, Indonesia. Advances in Language and Literary Studies, 9(4), 153-160. https://doi.org/10.7575/aiac.alls.v.9n.4p.153

Fahmi, R., Friatin, L., \& Irianti, L. (2020). The use of flipped classroom model in reading comprehension. JALL (Journal of Applied Linguistics and Literacy), 4(1), 77-94. Retrieved from https:/jurnal.unigal.ac.id/index.php/jall/article/view/3138

Firman, F. (2020). Dampak Covid-19 terhadap pembelajaran di Perguruan Tinggi. BIOMA: Jurnal Biologi Dan Pembelajarannya, 2(1), 14-20. Retrieved from https://ojs.unsulbar.ac.id/index.php/bioma/article/view/743 
Fitriani, L., \& Nurjamaludin, M. (2020). Efektivitas model Cooperative Integrated Reading and Composition untuk meningkatkan kemampuan membaca pemahaman cerita fiksi. In Bale Aksara (Vol. 1). Retrieved from https://journal.institutpendidikan.ac.id/index.php/baleaksara

Fong, C. M., \& Hoon, N. M. (2020). A Conceptual Framework: The Integration of SQ3R in Flipped Classroom Model for Chinese Reading Comprehension. International Journal of Academic Research in Progressive Education and Development, 9(2). https://doi.org/10.6007/IJARPED/v9-i2/7484

Halili, S. H., \& Zainuddin, Z. (2015). Flipping the Classroom: What We Know and What We Don'T. The Online Journal of Distance Education and E-Learning, 3(1). Retrieved from https://www.researchgate.net/publication/275535019_FLIPPING_THE_CLA SSROOM_WHAT_WE_KNOW_AND_WHAT_WE_DON'T

Harida, E. S. (2014). Students' Ability and Difficulties in Understanding English Text (A Study at English Program IAIN Padangsidimpuan). AL-Ta Lim, 21(3), 6. https://doi.org/10.15548/jt.v21i3.102

Harida, E. S. (2017). An evaluation on students' reading motivation and their reading comprehension of the English Department students IAIN Padangsidimpuan. TAZKIR: Jurnal Penelitian Ilmu-Ilmu Sosial Dan Keislaman, 3(1), 183-194. Retrieved from http://jurnal.iainpadangsidimpuan.ac.id/index.php/TZ/article/view/817/711

Harida, E. S. (2020). Students' Learning in Corona Virus Diseases 2019 (Covid-19) Situation. English Education: English Journal for Teaching and Learning, 08(01), 25-37. https://doi.org/10.24952/EE.V8I01.2675

Harida, E. S. (2021a). CIRC-b-FCL Model for Teaching Intermediate Reading in COVID-19 Era (A Study on the Validity of the Model). International Journal on Integrated Education, 4(10), 177-183. Retrieved from https://journals.researchparks.org/index.php/IJIE/article/view/2317/2229

Harida, E. S. (2021b). Developing Model Cooperative Integrated Reading and Composition based on Flipped Classroom Learning (CIRC-b-FCL) in Understanding Paragraph for University Students. Padang: Universitas Negeri Padang.

Harida, E. S. (2021c). The Validity of the CIRC-b-FCL Model. Padang.

Hassan Mahmoud, N. (2020). Using Flipped Classroom Learning Model in developing some EFL Reading Skills among students at the Faculty of Specific Education. In Journal of Studies and Searches of Specific Education. 
Retrieved

from

http://www.jse.zu.edu.eg/index.php/jse/article/viewFile/290/248

Mastura, M., \& Santaria, R. (2020). Dampak pandemi Covid-19 terhadap proses pengajaran bagi guru dan siswa. Jurnal Studi Guru Dan Pembelajaran, 3(2), 289-295. https://doi.org/10.30605/JSGP.3.2.2020.293

Riduwan. (2009). Belajar mudah penelitian untuk guru - karyawan dan peneliti pemula. Bandung: Alfabetar from /freecontents/index.php/buku/detail/belajar-mudah-penelitian-untuk-gurukaryawan-dan-peneliti-pemula-riduwan-31718.html

Ristanto, R. H., Rahayu, S., \& Mutmainah, S. (2021). Conceptual understanding of excretory system: implementing Cooperative Integrated Reading and Composition based on Scientific Approach. Participatory Educational Research (PER), 8(1), 28-47. https://doi.org/10.17275/per.21.2.8.1

Saputra, K. Y. (2015). Pengaruh proses pembelajaran dan motivasi belaajr terhadap hasil belajar IPS Siswa SMP Maulana Pegayaman. Media Neliti, 5. Retrieved from https://media.neliti.com/media/publications/5387-IDpengaruh-proses-pembelajaran-dan-motivasi-belajar-terhadap-hasil-belajarips-sis.pdf

Siregar, I., Dasopang, M. D., Margolang, K. U., Hilda, L., Siregar, F. A., Harahap, D., ... Asnah, A. (2019). Panduan Akademik Mahasiswa IAIN Padangsidimpuan. Padangsidimpuan: IAIN Padangsidimpuan.

Slavin, R. E., Madden, N. A., Farnish, A. M., \& Stevens, R. J. (1995). Cooperative Integrated Reading and composition: a brief overview. ERIC. Retrieved from https://files.eric.ed.gov/fulltext/ED378569.pdf

Sofiana, N. (2018). Developing Cooperative Integrated Reading and Composition-based Role-Playing game application as an alternative media in the reading learning. Journal on English as a Foreign Language, 8(2), 170. https://doi.org/10.23971/jefl.v8i2.887

Sudarmaji, I., Anwar, A. A. A., \& Mulyana, A. (2021). Developing students' speaking skills through Flipped Classroom Model. Journal of English Education and Teaching, 5(2), 188-200. https://doi.org/10.33369/JEET.5.2.188200

Tse, W. S., Choi, L. Y. A., \& Tang, W. S. (2019). Effects of video-based flipped class instruction on subject reading motivation. British Journal of Educational Technology, 50(1), 385-398. https://doi.org/10.1111/bjet.12569 
Tularam, G. A., \& Machiesella, P. (2018). Traditional vs non-traditional teaching and learning Strategies - the case of E-learning! International Journal for Mathematic Teaching and Learning, 19(1), 129-158. Retrieved from https://www.cimt.org.uk/ijmtl/index.php/IJMTL/article/view/21

Wijayanti, S. (2020). Indonesian Students' Reading Literacy. AInternational Conference on Research and Academic Community Services (ICRACOS 2019), 390. Atlantis Press. https://doi.org/10.2991/ICRACOS-19.2020.13 